\title{
DATA VISUALISASI SEBAGAI PENDUKUNG INVESTIGASI MEDIA SOSIAL
}

\author{
Suwito Pomalingo', Bambang Sugiantoro², Yudi Prayudi ${ }^{1}$ \\ 1'suwitopoms@gmail.com, 2bambang.sugiantoro@uin-suka.ac.id, 1prayudi@uii.ac.id \\ ${ }^{1}$ Universitas Islam Indonesia, ${ }^{2}$ Universitas Islam Negeri Sunan Kalijaga
}

\begin{abstract}
Abstrak
Media sosial adalah sebuah aplikasi yang dapat membuat setiap orang dapat berinteraksi satu sama lain serta dapat mengonsumsi informasi dengan cara berbagi konten dengan cepat, efisien, dan real time. Berbagai macam informasi mengenai aktivitas seseorang yang dapat kita temukan di media sosial, menjadikan media sosial dapat membantu melakukan investigasi. Beberapa penelitian sebelumnya, menggunakan visualisasi dengan beberapa metode graf untuk mempermudah proses analisis data di media sosial yang begitu berlimpah. Namun data yang digunakan hanya bersumber dari satu media sosial saja, sedangkan masih banyak informasi pada media sosial lainnya yang dapat digunakan sebagai sumber data untuk keperluan analisa. Dalam penelitian ini akan dilakukan visualisasi dengan metode graf berarah, kemudian menghitung nilai property jaringan dan nilai sentralitas untuk mengetahui node yang memiliki banyak aktifitas yang nantinya dilakukan pencarian yang mendalam untuk menemukan pola interaksi atau aktivitas. Berdasarkan hasil hitung sentralitas maka didapatkan pada akun Twitter dan Instagram memiliki interaksi yang banyak, hal ini dapat dilihat pada nilai indegree dan outdegree node tersebut. Berdasarkan hasil analisis pada penelitian ini didapatkan informasi yang penting untuk melakukan investigasi media sosial, seperti informasi tetang profil pengguna, postingan, komentar, halaman sosial media yang disukai, lokasi, serta timestamp yang semuanya itu dihubungkan oleh sebuah garis yang memiliki arah yang menunjukkan hubungan antara node tersebut.
\end{abstract}

Kata kunci: visualisasi, media sosial, graf berarah, social network analysis.

\begin{abstract}
Social media is an application that can make everyone interact with each other and can consume information by sharing content quickly, efficiently and real time. Various kinds of information about someone's activities that we can find on social media, making social media can help to conduct investigations. Some research, using visualization with several graph methods to facilitate the process of analyzing data on social media that is so abundant. But the data used only comes from one social media, while there is still a lot of information on other social media that can be used as data sources for analysis purposes. In this study visualization using the directed graph method will be carried out, then calculate the value of network property and the value of centrality to find out which nodes have many activities which will be carried out in depth searches to find patterns of interaction or activity. Based on the results of the calculated centrality, it is found that on Twitter and Instagram accounts there are many interactions, this can be seen in the value of the indegree and outdegree node. Based on the results of the analysis in this study, information that is important for investigating social media is obtained, such as information about user profiles, posts, comments, preferred social media pages, location, and timestamp, all of which are connected by a line that shows the relationship between the node.
\end{abstract}

Keywords: visualization, social media, directed graph, social network analysis.

\section{Pendahuluan}

Media sosial memungkinkan setiap orang dapat berinteraksi satu sama lain serta dapat mengonsumsi informasi dengan cara berbagi konten dengan cepat, efisien, dan real time. Saat ini jumlah pengguna media sosial meningkat dengan sangat cepat. Berdasarkan data statistik yang dikeluarkan oleh hootsuite.com, jumlah pengguna media sosial di seluruh dunia per-maret 2019 adalah sebanyak 3.48 miliar (gambar 1), dimana jumlah ini mengalami peningkatan $9 \%$ dari tahun sebelumnya. 
ILKOM Jurnal Ilmiah Volume 11 Nomor 2 Agustus 2019 Terakreditasi peringkat 3 SK. No. $28 /$ E/KPT/2019

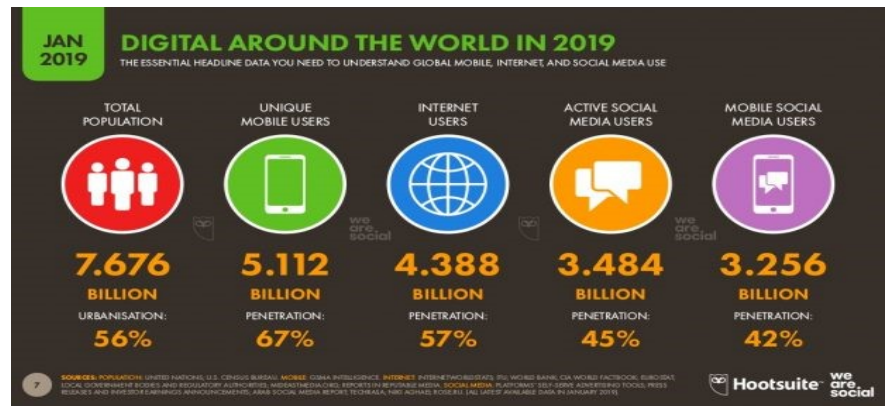

Gambar 1. Jumlah pengguna media sosial di seluruh dunia

Fitur dari media sosial yang dapat saling berbagi konten, pendapat, foto, berita, dan lainnya secara real time telah mengubah cara hidup sebagian besar manusia. Tidak hanya mengonsumsi informasi, setiap orang pun dapat memilih informasi yang mereka baca dan kemudian menyumbangkan konten dan opini mereka. Inilah yang disebut dengan Revolusi Sosial Media [1].

Beberapa informasi yang sering dibagikan di berbagai media sosial sebagian besar tentang aktivitas pengguna itu sendiri, dimana semua informasi tersebut meninggalkan jejak. Informasi yang ditemukkan pada media sosial dapat menunjukkan tentang kepribadian seseorang, teman, pola perilaku, dan lainnya. Hal inilah yang kemudian menjadikan media sosial menjadi alat yang dapat membantu untuk melakukan investigasi [2].

Pada tahun 2010 beberapa peneliti mengembangkan model investigasi digital forensik khusus untuk media sosial. Model investigasi yang dikembangkan menggunakan metode investigasi digital forensik yang umum digunakan, kemudian dikombinasikan dengan analisa secara terinci tentang bagaimana data yang diperoleh dari media sosial dapat mempengaruhi proses digital forensik, sehingga memenuhi persyaratan penting dari digital forensik [3]. Penelitian ini kemudian dikembangkan dengan merancang prototipe aplikasi untuk memastikan tujuan invesitgasi media sosial tercapai, dengan melakukan pengujian terhadap sejumlah studi kasus untuk memvalidasi desain prototipe [4].

Perkembangan media sosial yang terus meningkat secara signifikan yang diikuti dengan peningkatan perangkat digital (gambar 2) telah menyebabkan masalah besar yang mempengaruhi proses investigasi media sosial yang dituntut untuk menyajikan hasil analisis yang cepat dan tepat. Hal ini menjadi tantangan tersendiri dalam penelitian investigasi media sosial. Pemanfaatan API yang disediakan oleh media sosial, memudahkan dalam proses mengidentifikasi dan melakukan crawling data untuk selanjutnya dilakukan analisa dengan model visualisasi [5]. Data yang diambil seperti social footprint, pola komunikasi, video dan gambar, waktu aktivitas, dan aplikasi yang digunakan. Data tersebut kemudian divisualisasikan untuk mendapatkan informasi tentang Social Interconnection Graph, Social Interaction Graph, Complete Timeline, informasi lokasi, melacak aktivitas, pencocokan timeline. Penelitian ini berhasil mengidentifikasi data-data dari Facebook, yang kemudian dilakukan pemodelan visualisasi secara otomatis. Namun penelitian ini tidak mengambil data dari media sosial lainnya. Sehingga data yang divisualisasikan sangat minim informasi. Selain itu penelitian ini juga tidak memonitor perkembangan yang ada di media sosial yang setiap detik datanya bertambah. Sama halnya dengan penelitian yang menggunakan pendekatan taksonomi sederhana dalam memberikan ulasan mengenai tools yang digunakan untuk menganalisis media sosial, API dapat memudahkan dalam mendapatkan data tapi dengan beberapa perbedaan fitur media sosial, tingkat kedalaman data yang diambil akan berbeda [6]

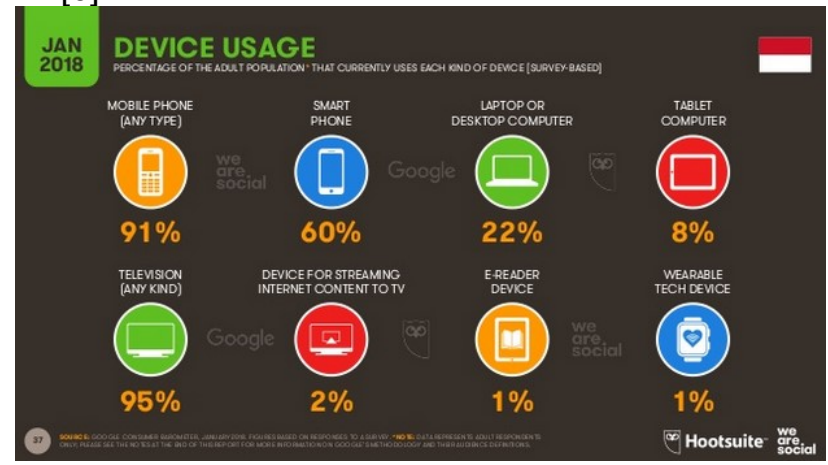

Gambar 2. Jumlah pengguna media sosial berdasarkan jenis perangkat digital 
ILKOM Jurnal Ilmiah Volume 11 Nomor 2 Agustus 2019 Terakreditasi peringkat 3 SK. No. 28/E/KPT/2019

Pendekatan metode investigasi digital forensik pada aplikasi media sosial, dapat memberikan rekomendasi untuk melakukan investigasi pada komputer yang terpasang aplikasi media sosial [7]. Namun tentunya informasi yang didapatkan sangatlah minim dikarenakan setiap pengguna dapat menggunakan aplikasi media sosial di setiap perangkat. Hal ini senada dengan penelitian yang melakukan investigasi dan analisa media sosial menggunakan layanan pengiriman pesan pada Firefox OS, dapat menunjukkan informasi yang tersimpan pada memori dan tidak terenkripsi [8].

Selanjutnya untuk melakukan analisis dari data yang bersumber dari berbagai macam media sosial, digunakan metode data mining, yakni dari proses data preprocessing, data cleaning, analisis, dan visualisasi [9]. Senada dengan beberapa penelitian sebelumnya bahwa metode visualisasi sangat ditekankan untuk digunakan untuk menganalisa data. Akan tetapi hasil dari visualisasi hanya dapat digunakan untuk mengetahui tren atau popularitas yang ada di media sosial. Sehingga tidak memungkinkan untuk mendapatkan informasi untuk keperluan investigasi. Pendekatan metode data analysis dan text mining, dalam hal ini dengan metode multidimensional scalling untuk mengklasifikasi, dapat memahami persepsi pengguna yang ada di media sosial [10]. Namun penelitian ini hanya menggunakan satu media sosial yakni Facebook.

Penggunaan metode graf dapat menjelaskan keterkaitan antara node dalam jejaring sosial [11], dimana keterhubungan dikarenakan adanya ikatan seperti pertemanan, pengetahuan, kepentingan dan lainnya. Dalam mempelajari aktivitas sekelompok hacker di media sosial, metode Algoritma Focal Structure Analysis dan Social Network Analysis dapat mengidentifikasi set node yang berpengaruh pada jejaring sosial. Dengan SNA dapat mengidentifikasi node yang kuat, node yang berfungsi sebagai jembatan antara node yang berbeda, dan kata kunci yang digunakan [12].

Metode visualisasi sangat berguna menganalisis data media sosial yang berjumlah jutaan dan miliaran. Oleh karena itu visualisasi berbasis graf sangat dianjutkan untuk menyederhanakan proses analisis [13]. Dalam penelitiannya, dikembangkan algoritma Page Rank dalam data set twitter untuk menemukan web yang penting berdasarkan link atau tautan antar halaman web. Serupa dengan penelitian sebelumnya dimana representasi grafik digunakan dalam melakukan analisis media sosial [11] dimana penelitiannya menjelaskan tentang bagaimana dua orang terkait satu sama lain serta bagaimana mereka mengakses sumber daya. Dalam jejaring sosial, setiap individu atau disebut node dihubungkan oleh satu atau lebih jenis interdependensi tertentu seperti pertemanan, kekerabatan, minat atau hobi, pengetahuan dan lainnya. Dengan teori graf dapat menyelidiki hubungan-hubungan antara node.

Beberapa penelitian diatas menjelaskan bahwa data yang digunakan untuk kebutuhan investigasi media sosial hanya berasal dari salah satu media sosial. Sedangkan kita tau bahwa saat ini antara media sosial yang satu dengan yang lainnya saling memiliki keterkaitan. Dengan memanfaatkan fasilitas Application Programming Interface yang tersedia di berbagai media sosial yang kemudian diintegrasikan sehingga mendapatkan sebuah visualisasi berupa graf berarah yang merepresentasikan data dari berbagai media sosial, dimana visualisasi graf berarah tersebut selain menghubungkan antara node, juga memiliki informasi yang menjelaskan keterhubungan antara node. Hal ini tentu saja dapat mendukung upaya dalam melakukan pemetaan data dari berbagai media sosial, sehingga memungkinkan hasil analisa tersebut dapat digunakan untuk keperluan investigasi. Metode visualisasi data berupa graf berarah yang saling terhubung diduga kuat dapat menyajikan hasil analisis untuk kebutuhan investigasi berbagai media sosial. Adapun jenis media sosial yang digunakan dalam penelitian ini adalah Facebook, Twitter, Instagram, dan Linkedln, dimana media sosial tersebut yang saat ini banyak digunakan oleh banyak orang.

\section{Metode}

Penelitian ini dilakukan dengan pendekatan Social Network Analysis, dimana visualisasi jaringan menggunakan model graph berarah atau directed graf. Untuk mendapatkan data dari berbagai media sosial, dalam penelitian ini menggunakan salah satu aplikasi yakni Maltego. Adapun data dan informasi yang digunakan dalam penelitian ini pada umumnya data email, alias, akun media sosial dan aktivitas pada media sosial. Selanjutnya dihitung nilai atribut dalam jaringan yang terdiri dari Total Node, Total Edges, Average Degree, Average Weighted Degree, Network Diameter. Sedangkan untuk nilai sentralitas yang akan dihitung berupa Degree Centrality, Betweenees Centrality, Closeness Centrality. Pada visualisasi dengan graf berarah terdapat dua macam sentralitas yakni sentralitas derajat masuk (indegree centrality) dan sentralitas derajat keluar (outdegree centrality). Closeness Centrality seluruh indicator nilai digunakan untuk mengidentifikasi simpul mana yang memiliki nilai interaksi lebih tinggi untuk selanjutnya dilakukan investigasi pada simpul tersebut. 
ILKOM Jurnal Ilmiah Volume 11 Nomor 2 Agustus 2019 Terakreditasi peringkat 3 SK. No. 28/E/KPT/2019

Data yang digunakan dalam penelitian ini adalah data yang berasal dari beberapa media sosial, dimana pengambilan data digunakan menggunakan aplikasi Maltego dengan memanfaatkan fasilitas transform hub yakni Social Links yang merupakan pihak ke-tiga yang menyediakan data dari media sosial.

Adapun tahapan yang dilakukan pada penelitian ini melalui beberapa tahapan sebagai berikut:

1) Studi Literatur

Untuk mendukung penulisan penelitian ini, dibutuhkan studi literatur dengan mengumpulkan sejumlah informasi sesuai topik penelitian terkait. Sumber informasi dapat berasal dari buku, dokumen presentasi, jurnal penelitian, atau bahan tertulis lainnya yang didapatkan dari beberapa sumber baik yang bersifat online maupun offline. Review hasil penelitian sebelumnya juga sangat diperlukan untuk memudahkan dalam menentukan novelty, sehingga dapat menunjang tujuan akhir dilakukannya penelitian ini

2) Persiapan Sistem

Untuk mempermudah penelitian, perlu dilakukan beberapa persiapan seperti mendesain kebutuhan analisis data, mengidentifikasi permasalahan yang ada di media sosial, serta mengidentifikasi jenis data. Selanjutnya memastikan aplikasi maltego dengan update terbaru telah terinstall, koneksi internet yang dapat mengakses berbagai media sosial, dan API yang digunakan untuk mendapatkan data dari media sosial. Dalam penelitian ini menggunakan hardware berupa Komputer dengan Processor Intel Core i-7 dengan RAM 32 GB. Aplikasi yang digunakan adalah Maltego dengan menggunakan API dari Social Links.

3) Pengumpulan Data

Tahapan berikutnya adalah mendapatkan data yang telah diidentifikasi sebelumnya. Sumber data didapatkan dari berbagai media sosial. Proses mengumpulkan data dan informasi sebagai pendukung penelitian ini perlu ditetapkan tujuan yang melatarbelakanginya. Dengan tujuan yang jelas dapat menentukan data yang relevan. Tidak hanya untuk pengumpulan data saja tetapi bagaimana data itu diperoleh.

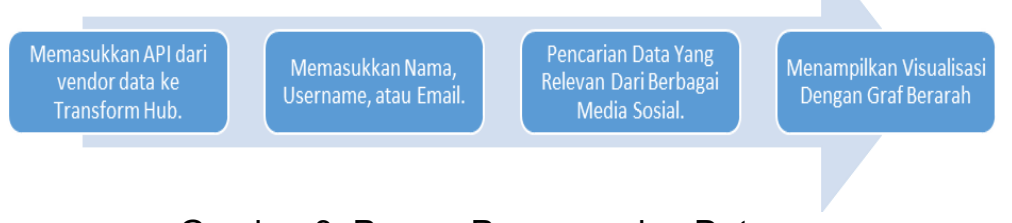

Gambar 3. Proses Pengumpulan Data

4) Analisis Data

Dalam proses pengolahan datanya, data yang diperoleh dari maltego akan divisualisasikan berdasarkan kebutuhan. Dengan mengubah beberapa tampilan pada Maltego, akan ditemukan informasi mengenai entitas atau node atau simpul yang menandakan bahwa simpul tersebut memiliki banyak aktivitas. Simpul yang dijadikan target investigasi kemudian akan diambil metadata untuk dilakukan analisa lebih dalam.

Selanjutnya untuk melakukan pengujian terhadap visualisasi data yang diperoleh dari Maltego, akan dilakukan proses pengujian dengan menggunakan aplikasi Gephi dimana data tersebut akan divisualisasikan kembali, dipetakan, difilter, dimanipulasi untuk mendapatkan beberapa nilai properti jaringan dan nilai sentralitas setiap simpul atau node. Data yang diperoleh dari Maltego akan diekspor dalam bentuk csv terlebih dahulu kemudian di impor ke Gephi. Nilai properti jaringan yang akan dihitung berupa Total Node, Total Edges, Average Degree, Average Weighted Degree, Network Diameter. Sedangkan untuk nilai sentralitas yang akan dihitung berupa Degree Centrality, Betweenees Centrality, Closeness Centrality. Pada visualisasi dengan graf berarah terdapat dua macam sentralitas yakni sentralitas derajat masuk (indegree centrality) dan sentralitas derajat keluar (outdegree centrality). Closeness Centrality dilakukan untuk mengetahui simpul mana yang menyebarkan informasi lebih cepat. Betweenes Centrality untuk mengetahui simpul mana yang penting dalam terjalinnya hubungan antar simpul yang tidak terhubung secara langsung [14].

5) Laporan Hasil Analisis Data

Proses terakhir dalam penelitian adalah membuat laporan hasil analisis investigasi media sosial. Laporan yang disusun diharapkan dapat memberikan gambaran secara menyeluruh mengenai 
ILKOM Jurnal Ilmiah Volume 11 Nomor 2 Agustus 2019

Terakreditasi peringkat 3 SK. No. 28/E/KPT/2019

topik penelitian ini, serta dapat memberikan rekomendasi yang bermanfaat untuk penelitianpenelitian selanjutnya.

\section{Hasil dan Pembahasan}

Proses pengumpulan dan pencarian data, menggunakan fasilitas Transforms Hub pada Maltego dimana dengan memasukkan satu jenis informasi atau entitas seperti nama, username, atau email dapat memberikan informasi lain seperti akun media sosial, postingan, komentar, dan lainnya. Selain itu dilakukan juga metode observasi langsung melalui website media sosial.

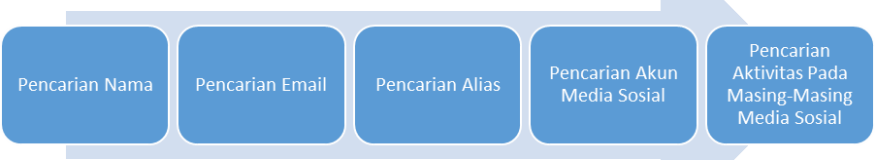

\section{Gambar 4. Proses Pencarian Data}

Setelah akun media sosial ditemukan, dilanjutkan dengan pencarian aktivitas pada media sosial tersebut. Pencarian dibatasi dengan 256 entitas. Namun sebelumnya perlu dilakukan verifikasi akun tersebut apakah real atau tidak dengan melakukan observasi langsung pada website media sosial. Pada penelitian ini, obyek yang digunakan adalah Raditya Dika, dimana obyek ini memiliki banyak akun media sosial.

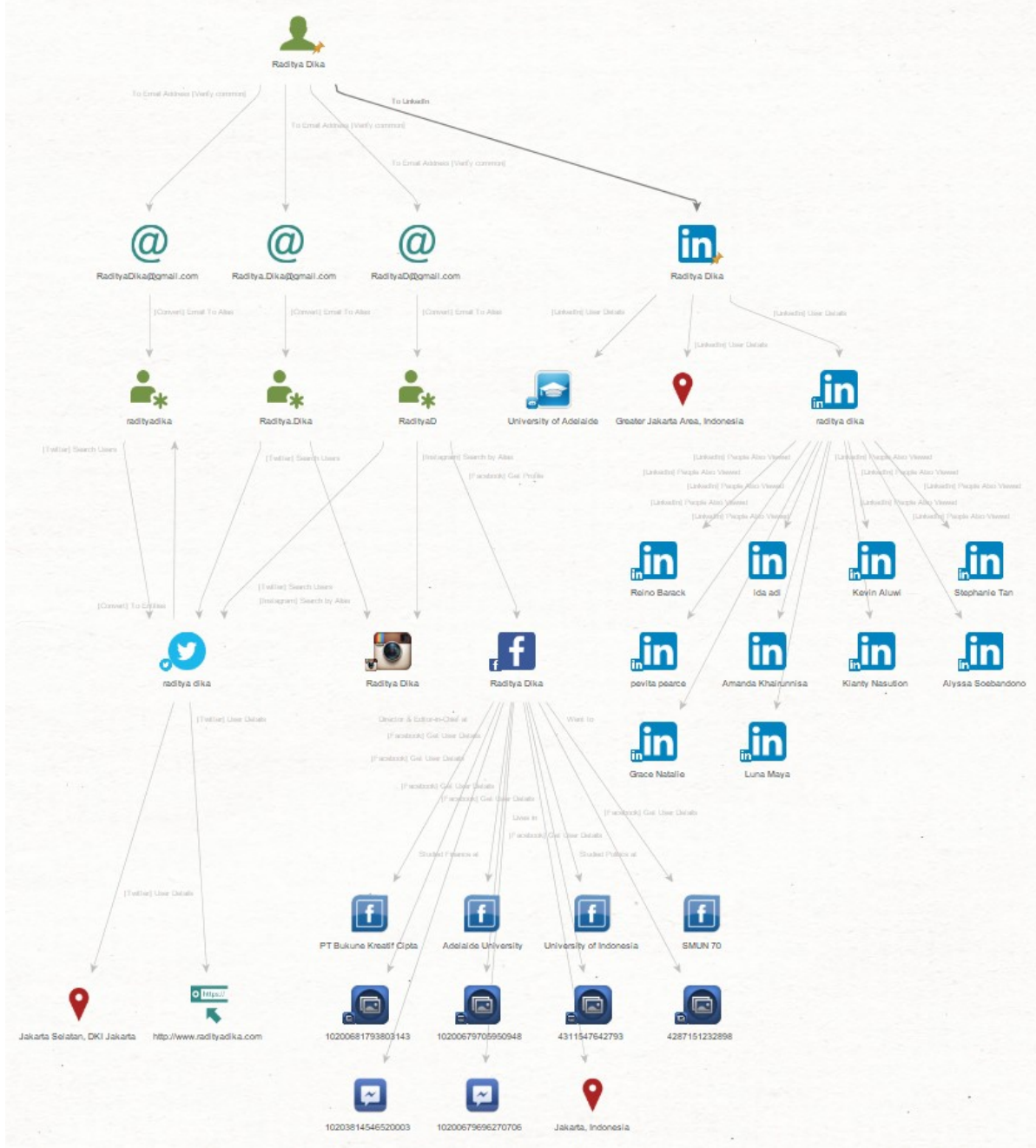


ILKOM Jurnal Ilmiah Volume 11 Nomor 2 Agustus 2019 Terakreditasi peringkat 3 SK. No. 28/E/KPT/2019

Gambar 5. Hasil pencarian data media sosial.

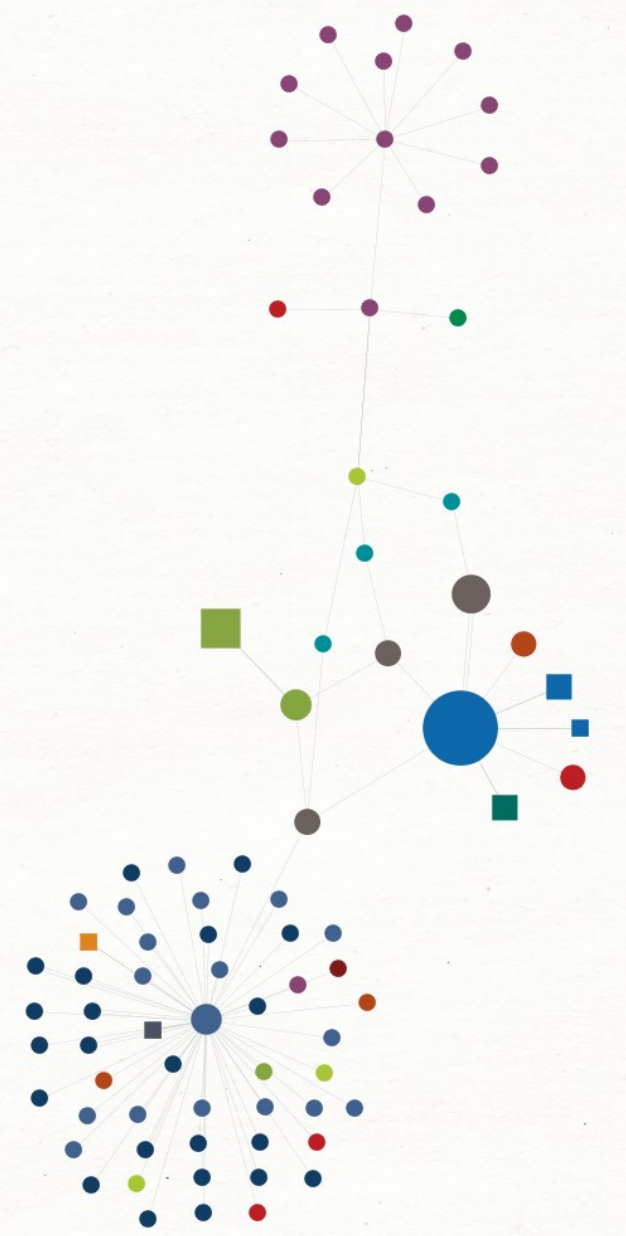

Gambar 6. Visualisasi berdasarkan banyaknya aktivitas pada media sosial.

Tabel 1. Ranking Incoming Link (Indegree)

$\begin{array}{llll}\text { Rank } & \text { Type } & \text { Value } & \text { Incoming links } \\ 1 & \text { Affiliation - Twitter } & \text { raditya dika } & 3003 \\ 2 & \text { radityadika } & \text { Raditya Dika } & 2 \\ 3 & \text { Facebook } & 10200681793803143 & 2 \\ 4 & \text { Facebook Photo } & 4287151232898 & 2 \\ 5 & \text { Facebook Photo } & 4311547642793 & 2 \\ 6 & \text { Facebook Photo } & 10200679705950948 & 2 \\ 7 & \text { Facebook Photo } & 10200679696270706 & 2 \\ 8 & \text { Facebook Post } & 10203814546520003 & 2 \\ 9 & \text { Facebook Post } & 97744291086 & 2 \\ 10 & \text { Facebook Post } & & 2\end{array}$

Tabel 2. Tabel Ranking Outgoing Link (Outdegree) 
ILKOM Jurnal Ilmiah Volume 11 Nomor 2 Agustus 2019

Terakreditasi peringkat 3 SK. No. 28/E/KPT/2019

$\begin{array}{llll}\text { Rank } & \text { Type } & \text { Value } & \text { Outgoing links } \\ 1 & \text { Affiliation - Twitter } & \text { raditya dika } & 4891 \\ 2 & \text { Instagram } & \text { Raditya Dika } & 334 \\ 3 & \text { Facebook } & \text { Raditya Dika } & 130 \\ 4 & \text { Linkedln } & \text { raditya dika } & 10 \\ 5 & \text { Person } & \text { Raditya Dika } & 4 \\ 6 & \text { Alias } & \text { RadityaD } & 3 \\ 7 & \text { Linkedln } & \text { Raditya Dika } & 3 \\ 8 & \text { Alias } & \text { Raditya.Dika } & 2 \\ 9 & \text { Alias } & \text { radityadika } & 1 \\ 10 & \text { Email Address } & \text { RadityaDika@gmail.com } & 1\end{array}$

Tabel 3. Rangking Total Link (Degree)

$\begin{array}{llll}\text { Rank } & \text { Type } & \text { Value } & \text { Total links } \\ 1 & \text { Affiliation - Twitter } & \text { raditya dika } & 7894 \\ 2 & \text { Instagram } & \text { Raditya Dika } & 336 \\ 3 & \text { Facebook } & \text { Raditya Dika } & 132 \\ 4 & \text { Linkedln } & \text { raditya dika } & 11 \\ 5 & \text { Person } & \text { Raditya Dika } & 4 \\ 6 & \text { Alias } & \text { RadityaD } & 4 \\ 7 & \text { Linkedln } & \text { Raditya Dika } & 4 \\ 8 & \text { Alias } & \text { Raditya.Dika } & 3 \\ 9 & \text { Alias } & \text { radityadika } & 3 \\ 10 & \text { Email Address } & \text { RadityaDika@gmail.com } & 2\end{array}$

Berdasaran hasil yang diperoleh seperti pada gambar 5 dan gambar 6 , yang kemudian dilakukan perhitungan sentralitas atau degree maka pengguna lebih banyak menggunakan Twitter dan Instagram. Oleh karena itu untuk keperluan investigasi, maka perlu dilakukan penelitian lebih dalam pada kedua akun media sosial tersebut.

Hasil yang diperoleh dari Maltego kemudian diexport menjadi tabel dengan format file csv. Yang kemudian diimport ke aplikasi Gephi untuk menentukan jumlah node serta nilai-nilai sentralitas. Data divisualisasikan ke dalam sociogram dimana titik pada gambar disebut node yang merepresentasikan entitas yang dihubungkan oleh garis yang disebut edge. Pada penelitian ini, algoritma yang digunakan untuk melakukan visualisasi pada Gephi adalah algoritma Fruchterman Reingnold [15]. Pada gambar 7 terlihat terdapat dua buah network yang memiliki banyak aktivitas. Seperti hasil yang ditemukan pada Maltego bahwa aktivitas terbanyak yang dilakukan oleh pengguna adalah Twitter kemudian Instagram seperti pada gambar 6 .

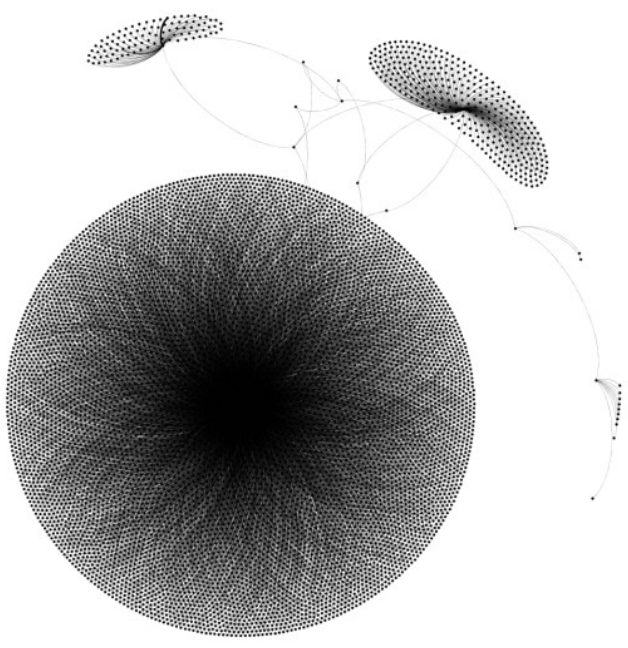

Gambar 7. Visualisasi dengan Gephi.

Tabel 4. Tabel perhitungan properti jaringan pada Gephi 
ILKOM Jurnal Ilmiah Volume 11 Nomor 2 Agustus 2019 Terakreditasi peringkat 3 SK. No. 28/E/KPT/2019

\begin{tabular}{cc}
\hline Properti Atribut Jaringan & Nilai \\
\hline Total Node & 8300 \\
\hline Total Edges & 8311 \\
\hline Average Degree & 1.001 \\
\hline Average Weighted Degree & 1.009 \\
\hline Network Diameter & 6 \\
\hline
\end{tabular}

Tabel 5. Tabel perhitungan nilai sentralitas pada Gephi

\begin{tabular}{|c|c|c|}
\hline Simpul/Node & Degree Centrality & $\begin{array}{l}\text { Closeness } \\
\text { Centrality }\end{array}$ \\
\hline
\end{tabular}

\begin{tabular}{lccccc}
\cline { 2 - 4 } & $\begin{array}{l}\text { Indegree } \\
\text { Centrality }\end{array}$ & $\begin{array}{c}\text { Outdegree } \\
\text { Centrality }\end{array}$ & $\begin{array}{c}\text { Degree } \\
\text { Centrality }\end{array}$ & & \\
\hline raditya dika & 2970 & 4889 & 7859 & 1.0 & 1.455 \\
\hline raditya_dika & 2 & 334 & 336 & 1.0 & 2000.8 \\
\hline $\mathbf{1 7 0 9 9 4 1 3 7 0}$ & 1 & 95 & 96 & 0.2031 & 319.0 \\
\hline $\begin{array}{l}\text { Raditya } \\
\text { Dika }\end{array}$ & 1 & 4 & 5 & 0.2504 & 5278.0 \\
& & & & & \\
\hline
\end{tabular}

Dari hasil tabel 3 terlihat bahwa node raditya dika memiliki derajat sentralitas yang jumlahnya besar yakni berjumlah 7894, hal ini mengindikasikan bahwa simpul ini memiliki banyak aktivitas dimana nilai outdegree bernilai 4891 yang berarti bahwa node ini memiliki aktivitas yang berarah keluar. Sedangkan node raditya dika memiliki nilai closeness 1.0 dan betweeness dengan nilai 1455 , yang berarti node ini sering digunkan sebagai penyebar informasi sehingga pengguna lain bisa melihat informasi tersebut.

Pada penelitian ini, dapat membuktikan bahwa dengan menggunakan metode visualisasi graf berarah dapat membantu dalam melakukan analisis investigas pada media sosial. Dengan menggunakan aplikasi Maltego maka akan mendapatkan banyak informasi dengan cepat. Pencarian yang dilakukan berdasarkan nama, maka ditemukan email dan alias dari pengguna tersebut. Berdasarkan nama, alias dan email inilah kemudian dilakukan pencarian informasi di media sosial seperti facebook, twitter, Instagram, dan Linkedln. Informasi mengenai postingan, like, dan komentar pengguna lain, timestamp, lokasi di beberapa media sosial dapat ditampilkan dengan graf berarah, sehingga memudahkan dalam menelusuri informasi yang dibutuhkan. Terlihat pada visualisasi menggunakan Maltego dan Gephi bahwa aktivitas terbanyak yang dilakukan oleh pengguna adalah Twitter, kemudian Instagram. Hal ini digambarkan melalui visualisasi pada gambar 7, selain itu dapat dilihat juga pada tabel 5 tentang total rangking link atau degree.

\section{Kesimpulan dan Saran}

Dari hasil penelitian yang telah dilakukan, untuk menjawab pertanyaan penelitian yang telah dikemukakan diawal, maka dapat diambil kesimpulan bahwa metode graf berarah dapat digunakan untuk melakukan analisa investigasi pada berbagai media sosial sehingga mendapatkan satu kesatuan visualisasi, dimana simpul atau node menggambarkan entitas seperti person, postingan, komentar, dan lainnya, dan sisi menggambarkan sebuah garis berarah yang menyatakan hubungan setiap simpul. Penggunaan graf berarah dapat membantu menyederhanakan proses investigasi pada berbagai media sosial. 
ILKOM Jurnal Ilmiah Volume 11 Nomor 2 Agustus 2019 Terakreditasi peringkat 3 SK. No. 28/E/KPT/2019

Data alias yang ditemukan dari email pengguna, dapat dilakukan sebagai dasar untuk mendapatkan informasi akun di media sosial. Yang selanjutnya dilakukan untuk mendapatkan banyak informasi dari masing-masing media sosial.

Berdasarkan hasil analisis pada penelitian ini didapatkan informasi yang penting untuk melakukan investigasi media sosial, seperti informasi tetang profil pengguna, postingan, komentar, halaman sosial media yang disukai, lokasi, serta timestamp yang semuanya itu dihubungkan oleh sebuah garis yang memiliki arah yang menunjukkan hubungan antara entitas tersebut.

Dari hasil penelitian, pengguna lebih banyak beraktivitas pada Twitter dan Facebook. Sehingga pada kedua akun ini perlu dilakukan investigasi yang lebih jauh untuk mendapatkan informasi yang relevan.

Saran untuk penelitian selanjutnya mengenai investigasi media sosial menggunakan metode visualisasi berarah perlu dilakukan pengujian berdasarkan framework forensik media sosial untuk menghasilkan informasi yang akurat dan lebih detail. Dalam penelitian selanjutnya dapat dilakukan dengan menggunakan visualisasi graf dengan metode selain graf berarah untuk investigasi pada berbagai media sosial.

\section{Ucapan Terima Kasih}

Penelitian ini tidak lepas dari dukungan dan bimbingan berbagai pihak. Penulis mengucapkan terimakasih sebesar-besarnya kepada Bapak Yudi Prayudi, M.Kom, selaku Kepala Pusat Studi Forensika Digital yang telah memberikan fasilitas penggunaan aplikasi Maltego sehingga sangat membantu dalam penyelesaian penelitian ini.

\section{Daftar Pustaka}

[1] R. A. Harper, "The Social Media Revolution Exploring the Impact on Journalism and News Media Organizations," Inq. Journal/Student Pulse, 2010.

[2] J. Golbeck and J. L. Klavans, Introduction to Social Media Investigation A Hands-on Approach. Syngress, 2015.

[3] N. M. Zainudin, M. Merabti, and D. Llewellyn-jones, "A Digital Forensic Investigation Model for Online Social Networking," 2010.

[4] N. M. Zainudin, M. Merabti, and D. Llewellyn-jones, "Online Social Networks As Supporting Evidence : A Digital Forensic Investigation Model and Its Application Design," 2012.

[5] M. Mulazzani, M. Huber, and E. Weippl, "Data Visualization For Social Network Forensics," in Advances in Digital Forensics VIII, 2012, pp. 115-126.

[6] B. Batrinca and P. C. Treleaven, "Social media analytics : a survey of techniques, tools and platforms," pp. 89-116, 2014.

[7] M. Taylor, J. Haggerty, D. Gresty, P. Almond, and T. Berry, "Forensic investigation of social networking applications," LJMU Res. Online, 2014.

[8] M. N. Yusoff, A. Dehghantanha, and R. Mahmod, "Forensic Investigation of Social Media and Instant Messaging Services in Firefox OS : Facebook, Twitter, Google +, Telegram , OpenWapp and Line as Case Studies," pp. 41-62, 2017.

[9] S. Patnaik and S. S. Barik, "Social Media Analytics using Visualization," vol. 7, no. 4, pp. 260267, 2018.

[10] Y. K. Tse, H. Loh, J. Ding, and M. Zhang, "An investigation of social media data during a product recall scandal," Enterp. Inf. Syst., vol. 0, no. 0, pp. 1-19, 2018.

[11] S. Mishra, R. Borboruah, B. Choudhury, and S. Rakhsit, "Modeling of Social Network using Graph Theoretical Approach," Int. J. Comput. Appl., pp. 34-37, 2014.

[12] S. Al-khateeb, K. J. Conlan, I. Baggili, and F. Breitinger, "Exploring Deviant Hacker Networks ( DHM ) on Social Media Platforms," J. Digit. Forensics, Secur. Law, vol. 11, no. 2, 2016.

[13] N. V. M. Lakshmi and T. L. Praveena, "A Review of Graph Based Algorithms in Social Media Data Analytics," JETIR, no. May, 2018.

[14] C. D. Correa and K.-L. Ma, "Visualizing Social Networks," Springer Sci. Media, 2011.

[15] T. M. J. Fruchterman and E. M. Reingold, "Graph Drawing by Force-directed Placement," vol. 21, no. June 1990, pp. 1129-1164, 1991. 